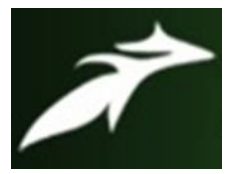

D. ABILA DOSS et al, International Journal of Advances in Agricultural Science and Technology,

Vol.7 Issue.10, October-2020, pg. 27-33

ISSN: 2348-1358

Impact Factor: 6.057

NAAS Rating: 3.77

\title{
STUDY ON INFORMATION NEEDS REGARDING CULTIVATION AND MARKETING CONSTRAINTS OF BANANA GROWERS IN AGASTEESWARAM TALUK OF KANYAKUMARI DISTRICT OF TAMIL NADU
}

\author{
D. ABILA DOSS ${ }^{1}$; DR. SYED H. MAZHAR ${ }^{2}$; UDANGSHRI BRAHMA ${ }^{3}$ \\ MSc Scholar, Associate Professor, MSc Scholar \\ Department of Agriculture Extension and Communication \\ Sam Higginbottom University of Agricultural Technology \& Sciences, Prayagraj (211007)
}

DOI: 10.47856/ijaast.2020.v07i10.006

\begin{abstract}
In Banana production India has first rank in the world. In agriculture, the production of fruits and vegetables are of so vital importance that it provide three to four time more income than cereals per unit of land. The fruit crops hold a great promise for accelerating income of the farmers. Realizing the importance of fruit cultivation many farmers are diverting their resources towards plantation of fruit crops. Area under fruit crops is, therefore, increasing day by day. Banana could be considered as poor man's apple and it is available throughout the year unlike seasonal availability of other fruits. Tamil Nadu state rank in banana production in India is first where area is 113.7 thousand hectare and production is 5136.2 thousand M.T. the banana in the state has been reportedly being cultivated under traditional manner (NHB, 2018-19). By and large, the farmers are cultivating only the traditional varieties of banana. The profitability of the banana products has not been quite substantial. The profitability of banana production depends upon the income generating capacity and cost structure of the enterprises. However, much information is not available on the economic aspect of banana cultivation at micro level. Hence a study encompassing the above-mentioned issues is a felt need and it is quite justified in taking up such a study. In order to find the solution to some of the problems discussed above, the present study has been contemplated in Kanyakumari.
\end{abstract}

KEYWORDS: Banana, Information needs, Socio-economic profile

\section{INTRODUCTION}

A banana is an edible fruit - botanically a berry - produced by several kinds of large herbaceous flowering plants in the genus Musa. In some countries, bananas used for cooking may be called "plantains", distinguishing them from dessert bananas. Banana is otherwise called as, "Apple of Paradise". The global production of banana is around 102028.17 thousand tons of which India contributes 29.19 percent. Besides India, other major banana producing countries are China, Philippines, Ecuador, Brazil and Indonesia. India ranks first in banana production. In India, Banana ranks next only to mango in area and production. Banana is an important fruit crop of many tropical and subtropical regions of India. It is cultivated in India in an area of 884 thousand ha and total production is 30808 thousand MT. Main banana growing states are Tamil Nadu, Maharashtra, Gujarat, Andhra Pradesh and Karnataka. 


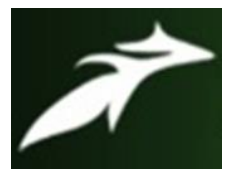

D. ABILA DOSS et al, International Journal of Advances in Agricultural Science and Technology,

\section{METHOD OF DATA COLLECTION}

Primary Data Collection: The primary data has been collected through survey and observation. Through schedule, data has been collected from the farmers of selected villages Schedule has been prepared with both close ended and open ended questionnaire.

Secondary Data Collection: The secondary data has been collected through different source of materials, websites and other exiting records, various books, magazines, official records, research paper, internet, journals, news articles and other exiting sources of data.

\section{STATISTICAL ANALYSIS OF DATA}

Data collected were qualitative as well as quantitative. Qualitative data were converted into quantitative data. The quantitative data were tabulated on the basis of logical categorization method. Percentage, Coefficient correlation and Microsoft Excel were used for analysis purpose.

\section{RESULTS AND DISCUSSION}

Table-1 : Distribution of Socio-economic Profile of the respondents

\begin{tabular}{|l|l|l|l|}
\hline Distribution of the respondents according to their age. & Percentage \\
\hline S.N. & Categories & Frequency & 19.16 \\
\hline $\mathbf{1}$ & Young (up to 20 to 35 years) & 23 & $\mathbf{5 8 . 3 4}$ \\
\hline $\mathbf{3}$ & Middle (36 to 55 years) & 70 & 22.50 \\
\hline & Old (Above 55 years) & 27 & $\mathbf{1 0 0}$ \\
\hline Distribution & Total the respondents according to their caste. & 12.50 \\
\hline 1. & General & 15 & $\mathbf{5 8 . 3 3}$ \\
\hline 2. & OBC & 70 & 25.00 \\
\hline 3. & SC & 30 & 04.17 \\
\hline 4. & ST & 5 & $\mathbf{1 0 0 . 0 0}$ \\
\hline & Total & $\mathbf{1 2 0}$ & \\
\hline & & & \\
\hline
\end{tabular}




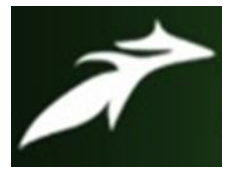

D. ABILA DOSS et al, International Journal of Advances in Agricultural Science and Technology,

\begin{tabular}{|c|c|c|c|}
\hline \multicolumn{4}{|c|}{ Distribution of the respondents according to their Educational. } \\
\hline 1 & Illiterate & 29 & 24.16 \\
\hline 2 & Primary school & 15 & 12.5 \\
\hline 3 & Secondary school & 16 & 13.35 \\
\hline 4 & High school & 17 & 14.16 \\
\hline 5 & Intermediate & 30 & 25 \\
\hline 6 & Graduation/PG & 13 & 10.83 \\
\hline & Total & 120 & 100.00 \\
\hline \multicolumn{4}{|c|}{ Distribution of the respondents according to their occupation. } \\
\hline 1 & Only Farming & 35 & 29.17 \\
\hline 2 & Farming + Animal husbandry & 41 & 34.17 \\
\hline 3 & Farming + Service & 23 & 19.16 \\
\hline 4 & Farming + Business & 21 & 17.50 \\
\hline & Total & 120 & 100 \\
\hline \multicolumn{4}{|c|}{ Distribution of the respondents according to their Land holding. } \\
\hline 1 & Marginal Farmers (Up to 1.00 ha) & 13 & 10.83 \\
\hline 2 & Small Farmers (1.00 to 2.00 ha) & 35 & 29.17 \\
\hline 3 & Medium Farmers (2.00 to $4.00 \mathrm{ha})$ & 43 & 35.83 \\
\hline 4 & Big Farmers (Above 4.00 ha) & 29 & 24.17 \\
\hline & Total & 120 & 100.00 \\
\hline \multicolumn{4}{|c|}{ Distribution of the respondents according to their Source of irrigation. } \\
\hline 1 & Canal & 43 & 35.83 \\
\hline 2 & Tube well & 14 & 11.67 \\
\hline 3 & Well & 21 & 17.50 \\
\hline 4 & River & 32 & 26.67 \\
\hline 5 & Other (Pond, etc.) & 10 & 8.33 \\
\hline & Total & 120 & 100.0 \\
\hline
\end{tabular}




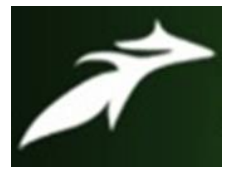

D. ABILA DOSS et al, International Journal of Advances in Agricultural Science and Technology,

\begin{tabular}{|c|c|c|c|c|}
\hline \multicolumn{5}{|c|}{ Distribution of the respondents according to their Farming Experience. } \\
\hline 1 & Low(below 10 year) & \multicolumn{2}{|l|}{27} & 22.50 \\
\hline 2 & Medium (10-20 year) & \multicolumn{2}{|l|}{43} & 35.83 \\
\hline 3 & High (above 20 year) & \multicolumn{2}{|l|}{50} & 41.67 \\
\hline & Total & \multicolumn{2}{|l|}{120} & 100.00 \\
\hline \multicolumn{5}{|c|}{ Distribution of the respondents according their Annual Income. } \\
\hline 1 & Low(30000-50000) & \multicolumn{2}{|l|}{45} & 37.50 \\
\hline 2 & Middle(51000-70000) & \multicolumn{2}{|l|}{43} & 35.83 \\
\hline 3 & $\operatorname{High}(71000-90000)$ & \multicolumn{2}{|l|}{32} & 26.67 \\
\hline & Total & \multicolumn{2}{|l|}{120} & 100.00 \\
\hline \multicolumn{5}{|c|}{ Distribution of the Respondents according to their Type of Family. } \\
\hline 1 & Joint & \multicolumn{2}{|l|}{52} & 43.33 \\
\hline 2 & Nuclear & \multicolumn{2}{|l|}{68} & 56.66 \\
\hline & Total & \multicolumn{2}{|l|}{120} & 100.00 \\
\hline \multicolumn{5}{|c|}{ Distribution of the respondents according to their size of family. } \\
\hline 1 & \multicolumn{2}{|l|}{ Small Family (up to 5 members) } & 49 & 40.83 \\
\hline 2 & \multicolumn{2}{|l|}{ Medium Family (6 to 10 Members) } & 37 & 30.83 \\
\hline 3 & \multicolumn{2}{|l|}{ Large family (Above 10 members) } & 34 & 28.34 \\
\hline & \multicolumn{2}{|l|}{ Total } & 120 & 100 \\
\hline \multicolumn{5}{|c|}{ Distribution of the respondents according to their Type of house. } \\
\hline 1 & Semi-cemented & \multicolumn{2}{|l|}{57} & 47.5 \\
\hline 2 & Cemented & \multicolumn{2}{|l|}{63} & 52.5 \\
\hline & Total & \multicolumn{2}{|l|}{120} & $100 \%$ \\
\hline \multicolumn{5}{|c|}{ Distribution of the respondents according their overall Extension participation } \\
\hline 1 & High & \multicolumn{2}{|c|}{18} & 15.00 \\
\hline 2 & Medium & \multicolumn{2}{|l|}{25} & 20.28 \\
\hline 3 & Low & \multicolumn{2}{|l|}{77} & 64.72 \\
\hline
\end{tabular}




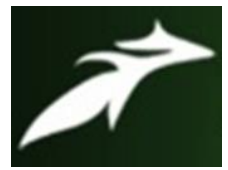

D. ABILA DOSS et al, International Journal of Advances in Agricultural Science and Technology, Vol.7 Issue.10, October-2020, pg. 27-33

ISSN: 2348-1358

Impact Factor: 6.057

NAAS Rating: 3.77

\begin{tabular}{|l|l|l|l|l|}
\hline \multicolumn{2}{|l|}{} & Total & $\mathbf{1 2 0}$ & $\mathbf{1 0 0 . 0 0}$ \\
\hline \multicolumn{4}{|l|}{ Distribution of the respondents according to their overall Social participation. } \\
\hline 1 & High & 14 & 11.67 \\
\hline 2 & Medium & 17 & 14.17 \\
\hline 3 & Low & 89 & $\mathbf{7 4 . 1 6}$ \\
\hline & Total & $\mathbf{1 2 0}$ & $\mathbf{1 0 0 . 0 0}$ \\
\hline Distribution of the respondents according to their Overall Source of Information. \\
\hline 1 & High & 28 & 23.33 \\
\hline 2 & Medium & 66 & $\mathbf{5 5 . 0 0}$ \\
\hline 3 & Low & 26 & 21.67 \\
\hline & Total & $\mathbf{1 2 0}$ & $\mathbf{1 0 0 . 0 0}$ \\
\hline
\end{tabular}

\section{INFORMATION NEEDS}

Table-2 : Distribution of the respondents according to the information needs

\begin{tabular}{|c|c|c|c|c|}
\hline S.N. & Statements & Areas of infe & on needs & \\
\hline & & $\begin{array}{l}\text { Fully } \\
\text { information } \\
\text { F. }(\%)\end{array}$ & $\begin{array}{l}\text { Partially } \\
\text { information } \\
\text { F. }(\%)\end{array}$ & \begin{tabular}{|l|} 
Not \\
information \\
F. $(\%)$
\end{tabular} \\
\hline 1 & Weather & $43 \quad(35.84)$ & $58(48.33)$ & $19(15.83)$ \\
\hline 2 & Soil and soil preparation & $44 \quad(36.67)$ & $\begin{array}{ll}56 & (46.66)\end{array}$ & $20(16.67)$ \\
\hline 3 & Variety & $47 \quad(39.17)$ & $55 \quad(45.83)$ & $18(15.00)$ \\
\hline 4 & Transplanting & $41 \quad(34.16)$ & 62 (51.67) & $17(14.17)$ \\
\hline 5 & Fertilizer management & $35 \quad(29.17)$ & $70(58.34)$ & $15(12.5)$ \\
\hline 6 & Irrigation management & $47 \quad(39.17)$ & $65(54.17)$ & $8(6.66)$ \\
\hline 7 & Intercultural and intercropping & $47 \quad(39.17)$ & $66(55.00)$ & $7(5.83)$ \\
\hline 8 & Weeds management & 52 (43.33) & $60 \quad(50)$ & $8(6.67)$ \\
\hline
\end{tabular}




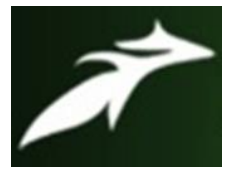

D. ABILA DOSS et al, International Journal of Advances in Agricultural Science and Technology, Vol.7 Issue.10, October-2020, pg. 27-33

ISSN: 2348-1358

Impact Factor: 6.057

NAAS Rating: 3.77

\begin{tabular}{|l|l|ll|ll|ll|}
\hline $\mathbf{9}$ & Plant protection & 28 & $(23.33)$ & 59 & $(49.17)$ & 33 & $(27.5)$ \\
\hline $\mathbf{1 0}$ & Harvesting and post harvesting & 38 & $(31.67)$ & 65 & $(54.17)$ & $17 \quad(14.16)$ \\
\hline $\mathbf{1 1}$ & Market management & 42 & $(35.00)$ & 57 & $(47.50)$ & $21 \quad(17.50)$ \\
\hline
\end{tabular}

Table-3 : Distribution of respondents according to their overall information needs

\begin{tabular}{|l|l|l|l|}
\hline S.N. & Information needs & Frequency & Percentage \\
\hline $\mathbf{1}$ & Low (11-18) & 21 & 16.08 \\
\hline $\mathbf{2}$ & Medium 19-25) & 60 & $\mathbf{5 0 . 0 0}$ \\
\hline $\mathbf{3}$ & High (26-33) & 39 & 33.92 \\
\hline $\mathbf{4}$ & Total & $\mathbf{1 2 0}$ & $\mathbf{1 0 0 . 0 0}$ \\
\hline
\end{tabular}

The data in the above table showed that most of the respondents 50 percent had medium information needs followed by 33.92 percent high information needs and 16.08 percent fell in low information needs respectively.

Table-4: Relationship between socio-economic and their information needs of banana growers.

\begin{tabular}{|l|l|l|}
\hline S.N. & Characteristics & "r" value \\
\hline $\mathbf{1}$ & Age & $-0.01300 \mathrm{NS}$ \\
\hline $\mathbf{2}$ & Education & $0.17640 \mathrm{NS}$ \\
\hline $\mathbf{3}$ & Occupation & $0.02459^{*}$ \\
\hline $\mathbf{4}$ & Land holding & $0.18331 \mathrm{NS}$ \\
\hline $\mathbf{5}$ & Size of family & $0.03913^{*}$ \\
\hline $\mathbf{6}$ & Annual income & $0.17503 \mathrm{NS}$ \\
\hline $\mathbf{7}$ & Irrigation & $0.03073 \mathrm{NS}$ \\
\hline $\mathbf{8}$ & Extension participation & $0.21307^{*}$ \\
\hline $\mathbf{9}$ & Information needs & $0.04292^{*}$ \\
\hline
\end{tabular}

$*=$ Significant at $\mathrm{p}=0.05, \mathrm{NS}=$ Non significant 


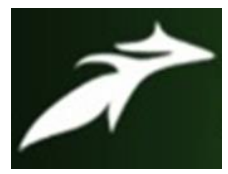

D. ABILA DOSS et al, International Journal of Advances in Agricultural Science and Technology, Vol.7 Issue.10, October-2020, pg. 27-33

The data from the above table shows that, occupation, size of family, extension participation, information needs are positively significant at $0.05 \%$ whereas education, land holding, annual income, irrigation are positive but non-significant at $0.05 \%$ and age negative and non-significant at $0.05 \%$ of the respondent respectively.

\section{CONCLUSION}

It can be concluded that most of the respondents (55\%) had medium source of information followed by $(23.33 \%)$ high and $(21.67 \%)$ low and the relationship between information needs and socio-economic profile of respondents shows that family size $\left(0.03913^{*}\right)$, occupation $\left(0.02459^{*}\right)$ participation in extension activities $\left(0.21307^{*}\right)$, and information needs $\left(0.04292^{*}\right)$ were positively and significantly at $0.05 \%$ whereas education $(0.17640 \mathrm{NS})$, land holding (0.18331NS.), irrigation (0.03073NS) and annual income (0.17503NS) were found to positively but non-significant and age (-0.01300NS) negative but non-significant at $0.05 \%$ to extent the adoption of the respondent respectively. Hence it is imperative that government and the experts should take more steps like training, field demonstration, more interaction with the farmers, more government schemes, loans so that more people can improve their production with more information as it also generates lots of employment which will help in the upliftment of society.

\section{REFERENCES}

[1]. Anonymous (2003-04), Annual report of Department of Horticulture, Gandhinagar.

[2]. Anonymous (2004), CMIE- (Indian harvest database), Centre for monitoring Indian economy subscription.

[3]. Bhople, R.S., shinde, P.S. and Nimje, V.R. (1996) Production and marketing constraints faced by orange growers. Maha. J. Extn. Edu. Vol. XV: 57-61.

[4]. Brahmbhatt, N.B.(1998), Economic of production and marketing of banana in kheda district of middle Gujarat, unpublished M.Sc. (Agri.) thesis, GAU, Anand.

[5]. Chanda, K.L. (2001), Hand book of Horticulture, ICAR, Publication- New Delhi.

[6]. Gouda,K.C. (1995), Extent of adoption of banana cultivation technology by the farmers of Anand taluka. Unpublished M.Sc.(Agri.) thesis GAU, Anand. 